\title{
PENERAPAN ASAS ULTIMUM REMEDIUM DALAM PENEGAKAN HUKUM PIDANA LINGKUNGAN HIDUP
}

\author{
Imam Budi Santoso ${ }^{1}$, Taun ${ }^{2}$. \\ Fakultas Hukum Universitas Singaperbangsa \\ ${ }^{1}$ Email: ibskrw@yahoo.co.id \\ ${ }^{2}$ Email: taun84@yahoo.com
}

\begin{abstract}
The enforcement of environmental law in Indonesia today is growing, environmental laws and regulations are continuously equipped for sustainable development. But, enforcement of environmental law is still not as expected, in environmental law enforcement there are several ways of settlement that must be taken, administratively, alternatives dispute resolution and criminal law, but in criminal law enforcement regulated in Article 100 paragraph (2) of Law Number 32 Year 2009 on Environmental Protection and Management, criminal acts can only be applied if the administrative sanction is not complied with or violation is more than one time, then in explanation point 6 of Law Number 32 Year 2009 on Environmental Protection and Management, enforcement of environmental criminal law should pay attention to the principle of ultimum remedium which requires the application of criminal law enforcement as a last resort after the implementation of administrative law enforcement is deemed unsuccessful, and the application of the ultimum remedium principle applies only to certain offensive crimes, namely the prosecution of violations of waste water quality standards, emissions, and disturbances. However, if it is related to the legality principle contained in Article 1 paragraph (1) of the Criminal Code and the basis of criminal abrogation, the ultimum remedium principle is contradictory, criminal law should continue based on the principle of legality and stopped by the ultimum remedium principle on the basis of criminal sanction, whereas the basis of criminal abrogation has been clearly defined in the Criminal Code.
\end{abstract}

Keywords: environmental criminal law, ultimum remeidum principle, legality principle, criminal elimination.

\section{Pendahuluan}

Penegakan hukum lingkungan di Indonesia dewasa ini semakin berkembang dan peraturan perundang-undangan lingkungan terus dilengkapi dalam rangka pembangunan berkelnjutan, namun penegakan hukum lingkungan masih belum sesuai yang diharapkan, dalam penegakan hukum lingkungan terdapat beberapa cara penyelesaian yang harus ditempuh, yaitu secara administrasi, perdata, alternative penyelesaian sengketa, dan pidana, namun dalam penegakan hukum pidana diatur dalam Pasal 100 ayat (2) Undang-Undang Nomor 32 Tahun 2009 tentang Perlindungan dan Pengelolaan Lingkungan Hidup, tindak pidana hanya bisa diterapkan apabila sanksi administratif yang dijatuhkan tidak dipatuhi atau pelanggaran dilakukan lebih dari satu kali, kemudian dalam penjelasan angka 6 
Undang-Undang Nomor 32 Tahun 2009 tentang Perlindungan dan Pengelolaan Lingkungan Hidup, penegakan hukum pidana lingkungan harus memperhatikan asas ultimum remedium yang mewajibkan penerapan penegakan hukum pidana sebagai sebagai upaya terakhir setelah penerapan penegakan hukum administrasi dianggap tidak berhasil, dan penerapan asas ultimum remedium ini hanya berlaku bagi tindak pidana fromil tertentu, yaitu pemidanaan terhadap pelanggaran baku mutu air limbah, emisi, dan gangguan.

Sedangkan prinsip umum yang tertuang dalam dalam KUHP maupun KUHAP, menyatakan tiada suatu perbuatan dapat dipidana kecuali atas kekuatan aturan pidana dalam perundang-undangan (principle of legality). ${ }^{1}$ Artinya ketika suatu perbuatan yang melawan hukum telah diatur dalam peraturan perundang-undangan, maka hal tersebut dapat dipidana.

Namun dalam penegakan hukum pidana lingkungan menentang prinsip tersebut, dengan dituangkannya Pasal 100 ayat (2) Undang-Undang Nomor 32 Tahun 2009 tentang Perlindungan dan Pengelolaan Lingkungan Hidup kemudian yang dikuatkan dalam penjelasan angka 6 Undang-Undang Nomor 32 Tahun 2009 tentang Perlindungan dan Pengelolaan Lingkungan Hidup, yang

\footnotetext{
${ }^{1}$ Machmud, Syahrul (2012) Problematika Penerapan Delik Formil dalam Persepektif Penegakan Hukum Pidana Lingkungan di Indoensia, Bandung, CV. Mandar Maju, 2012, hlm. 123.
}

pada intinya adalah penegakan hukum pidana lingungan hanya bisa diterapkan apabila penerapan penegakan hukum administrasi dianggap tidak berhasil.

Dari penerapan asas ultimum remedium tersebut akan mempersulit penegak hukum dalam menegakan hukum pidana lingkungan, dengan asas ultimum remedium ini dapat membelenggu aparat penegak hukum dalam melaksanakan tugas penegakan hukum lingkungan, selain itu asas ultimum remedium ini juga dapat merugikan lingkungan karena terhadap pelaku pelanggaran baku mutu air limbah, emisi, dan gangguan yang diutamakan adalah pemberian sanksi administartif, artinya tidak ada efek jera terhadap pelaku dalam melakukan pelanggaran baku mutu air limbah, emisi, dan gangguan. penerapan sanski adminsitratif ini baik apabila langsung dipatuhi dan tidak mengulangi perbuatan serupa, namun ketika tidak dipatuhi apalagi setelah dipatuhi kemudian mengulangi perbuatan serupa, hal ini tentu akan lebih merusak lingkungan hidup.

Berdasarkan latar belakang dikemukakan diatas, maka yang menjadi permasalahan dalam penulisan ini adalah bagaimana singkronisasi asas ultimum remedium dalam penegakan hukum pidana lingkungan terhadap prinsip umum hukum pidana.

\section{Metode Penelitian}

Rancangan ini menggunakan pendekatan yuridis normatif, yaitu jenis pendekatan yang 
mengkaji atau menganalisis data sekunder seperti bahan pustaka atau data sekunder yang terdiri dari bahan hukum primer, bahan hukum sekunder dan bahan hukum tersier. Bahan-bahan tersebut disusun secara sistematis, dikaji kemudian dibandingkan dan ditarik kesimpulan dalam hubungannya dengan masalah yang diteliti.

Pendekatan penelitian yang digunakan dalam penelitian hukum ini yakni meliputi Statute Approach (Pendekatan Perundangundangan) dan Conceptual Approach (Pendekatan Konsep).

Pendekatan Konsep atau Conceptual Approach dilakukan untuk mempelajari konsep-konsep terkait dengan asas legalitas dan dasar peniadaan pidana yang juga menjadi fokus dalam isu hukum terkait tema penelitian. Pendekatan Perundang-undangan atau Statute Approach ialah pendekatan dengan menggunakan legislasi dan regulasi. ${ }^{2}$ Dalam penelitian ini pendekatan dilakukan dengan menelaah peraturan perundang undangan maupun hukum positif yang berlaku di negara Indonesia khususnya yang berkaitan dengan asas ultimum remedium, asas legalitas, dan dasar peniadaan pidana yang juga menjadi fokus dalam isu hukum terkait tema penelitian.

Bahan hukum yang digunakan dalam penelitian ini adalah bahan hukum primer yaitu bahan hukum yang bersifat autoritatif

\footnotetext{
${ }^{4}$ Ibrahim, Johnny (2007), Teori dan Metodologi Penelitian Hukum Normatif, Malang: Bayumedia Publishing, hlm. 57.
}

artinya mempunyai otoritas, terdiri dari perundang-undangan, risalah pembuatan perundang-undangan dan putusan-putusan hakim. ${ }^{3}$ Bahan hukum primer dalam karya tulis ini meliputi: 1) Kitab Undang-Undang Hukum Pidana; 2) Undang-Undang Nomor 32 Tahun 2009 tentang Perlindungan dan Pengelolaan Lingkungan Hidup.

Bahan hukum sekunder, yaitu buku teks karena buku teks berisi prinsip-prinsip dasar ilmu hukum dan pandangan-pandangan klasik para sarjana yang mempunyai kualifikasi tinggi. ${ }^{4}$ Literatur-literatur yang terkait permasalahan inilah yang masuk kualifikasi bahan hukum sekunder yang terkait permasalahan yang dikaji, antara lain: 1) Buku-buku hasil penelitian; 2) Pendapat dan doktrin para sarjana.

Bahan hukum tersier, yaitu bahan hukum yang memberikan penjelasan bahan hukum primer dan sekunder terutama mengenai istilah-istilah, yang terdiri dari :1) Kamus Hukum; 2) Kamus Besar Bahasa Indonesia; 3) Kamus Terjemahan Inggris-Indonesia.

\section{Analisis dan Pembahasan}

Penegakan hukum lingkungan di Indonesia mencakup penataan dan penindakan (compliance and enforcement) yang meliputi bidang hukum administrasi negara, bidang hukum perdata dan bidang

\footnotetext{
${ }^{5}$ Ibid, hlm 141.

${ }^{6}$ Ibid, hlm 142.
} 
hukum pidana, ${ }^{5}$ artinya dalam penegakan hukum lingkungan harus ditempuh terlebih dahulu melalui bidang hukum administrasi, adapun penyelesaian melalui bidang hukum pidana adalah merupakan upaya terakhir.

Dalam Undang-Undang Nomor 32 Tahun 2009 tentang Perlindungan dan Pengelolaan Lingkungan Hidup dikenal dengan asas ultimum remedium, namun sebelum berlakunya Undang-Undang Nomor 32 Tahun 2009 tentang Perlindungan dan Pengelolaan Lingkungan Hidup, sebelumnya berlaku Undang-Undang Nomor 4 Tahun 1982 tentang Pokok-Pokok Pengelolaan Lingkungan Hidup yang kemudian diperbaharui dengan Undang-Undang Nomor 23 Tahun 1997 tentang Pengelolaan Lingkungan Hidup, ${ }^{6}$ dikenal asas subsidaritas kemudian asas subsidaritas ini dihapus dan diganti dengan asas ultimum remedium sebagaimana tercantum pada penjelasan umum angka 6 Undang-Undang Nomor 32 Tahun 2009 tentang Perlindungan dan Pengelolaan Lingkungan Hidup, alasan penghapusan asas subsidaritas dapat kita baca pada naskah akademik RUU UUPPLH, bahwa asas subsidaritas merupakan salah satu masalah pada penerapan atau praktek hukum lingkungan karena ketidakjelasan makna asas tersebut, oleh karena itu kata asas subsidaritas dihapus dan diganti dengan

\footnotetext{
${ }^{5}$ Prof. Dr. M. Daud Silalahi, S.H, Hukum Lingkungan dalam sistem penegakan hukum lingkungan Indoensia, PT. Alumni, Bandung, 2014, Hlm. 215.

${ }^{6}$ DR. Syahrul Machmud, Op. Cit, Hlm. 1,
}

asas ultimum remedium dengan dipertegas bahwa asas tersebut hanya dapat diterapkan pada delik formil tertentu yaitu pelanggaran terhadap baku mutu air limbah, emisi dan gangguan. $^{7}$

Asas ultimum remedium diatur dalam penjelasan angka 6 Undang-Undang Nomor 32 Tahun 2009 tentang Perlindungan dan Pengelolaan Lingkungan Hidup, yang berbunyi:

Penegakan hukum pidana dalam Undang-Undang ini memperkenalkan ancaman hukuman minimum di samping maksimum, perluasan alat bukti, pemidanaan bagi pelanggaran baku mutu, keterpaduan penegakan hukum pidana, dan pengaturan tindak pidana korporasi. Penegakan hukum pidana lingkungan tetap memperhatikan asas ultimum remedium yang mewajibkan penerapan penegakan hukum pidana sebagai upaya terakhir setelah penerapan penegakan hukum administrasi dianggap tidak berhasil. Penerapan asas ultimum remedium ini hanya berlaku bagi tindak pidana formil tertentu, yaitu pemidanaan terhadap pelanggaran baku mutu air limbah, emisi, dan gangguan.

Pada intinya asas ultimum remeidum ini mengatur tentang penegakan hukum pidana lingkungan sebagai upaya terakhir setelah penerapan penegakan hukum administrasi dianggap tidak berhasil.

Namun asas ultimum remedium ini jika dikaitkan dengan prinsip umum dalam hukum pidana terdapat pertentangan, yaitu: Asas Legalitas.

\footnotetext{
${ }^{7}$ Ibid, Hlm, 15
} 
Asas legalitas tercantum dalam Pasal 1 ayat (1) KUHP, kalau kata-katanya yang asli dalam bahasa Belanda disalin ke dalam bahasa Indoensia kata demi kata, maka akan berbunyi: "Tiada suatu perbuatan (feit) yang dapat dipidana, selain berdasarkan kekuatan ketentuan perundang-undangan pidana yang mendahuluinya". 8

Artinya ketika ada peraturan perundangundangan yang mengatur tentang suatu tindak pidana, maka terhadap orang yang melanggar aturan tersebut berdasarkan asas legalitas harus dipidana, demikian pula dengan yang diatur dalam Pasal 100 Undang-Undang Nomor 32 Tahun 2009 tentang Perlindungan dan Pengelolaan Lingkungan Hidup, yaitu:

(1) Setiap orang yang melanggar baku mutu air limbah, baku mutu emisi, atau baku mutu gangguan dipidana, dengan pidana penjara paling lama 3 (tiga) tahun dan denda paling banyak Rp3.000.000.000,00 (tiga miliar rupiah).

(2) Tindak pidana sebagaimana dimaksud pada ayat (1) hanya dapat dikenakan apabila sanksi administratif yang telah dijatuhkan tidak dipatuhi atau pelanggaran dilakukan lebih dari satu kali.

Dalam Pasal 100 ayat (1) tersebut sudah jelas rumusan tindak pidana dan hukuman yang diterima bagi orang yang melanggar pasal tersebut, dan jika dikaitkan dengan asas legalitas maka ketika ada yang melanggar pasal tersebut seketika itu pula pidana

\footnotetext{
${ }^{8}$ Prof. Dr. Jur. Andi Hamzah, Hukum Pidana, PT. Sofmedia, Jakarta, 2015, Hlm. 49.
}

berjalan, ditambah dengan tindak pidana dalam Undang-Undang Nomor 32 Tahun 2009 tentang Perlindungan dan Pengelolaan Lingkungan Hidup adalah merupakan kejahatan, sebagaimana diatur dalam Pasal 97, yaitu: "Tindak pidana dalam undangundang ini merupakan kejahatan", maka sedikit keliru penulisan kata "pelanggaran" dalam Pasal 100 ayat (2) diatas, yang seharusnya berdasarkan Pasal 97 tindak pidana ini merupakan kejahatan.

Meoljatno, menulis bahwa asas legalitas itu mengandung tiga pengertian, yaitu: ${ }^{9}$

1. Tidak ada perbuatan yang dilarang dan diancam dengan pidana kalau hal itu terlebih dahulu belum dinyatakan dalam suatu undang-udang;

2. Untuk menentukan adanya perbuatan pidana tidak boleh digunakan analogi;

3. Aturan-aturan hukum pidana tidak berlaku surut.

Artinya dalam pengaturan Pasal 100 ayat (1) tersebut diatas, sudah jelas adanya perbuatan yang dilarang, unsur-unsurnya sudah jelas yang seharusnya tidak diperlukan lagi Pasal 100 ayat (2) tersebut.

Sehingga dengan berlakunya asas legalitas tersebut pada Pasal 100 ayat (1), maka muncul tiga aturan menurut Von Feurbach, yaitu: ${ }^{10}$

\footnotetext{
${ }^{9}$ Ibid, Hlm. 50

${ }^{10}$ Ibid, hlm. 52-53.
} 
1. Setiap pengenaan pidana didasarkan hanya pada undang-undang (nulla poena sine lege);

2. Pengenaan pidana hanya mungkin, jika perbuatan yang terjadi diancam dengan pidana (nulla poena sine crimine);

3. Perbuatan yang diancam dengan pidana berdasarkan undang-undang mempunyai akibat hukum bahwa oleh undang-undang ada pidana untuk itu (nullum crimen sine poena legali).

Artinya ketika asas legalitas melekat pada Pasal 100 ayat (1) tersebut, maka pengenaan pidana terhadap pelanggaran pasal tersebut hanya didasarkan pada pasal itu, yaitu pidana penjara paling lama 3 (tiga) tahun dan denda paling banyak Rp3.000.000.000,00 (tiga miliar rupiah), sehingga dalam Pasal 100 ayat (1) sudah jelas bahwa pasal tersebut terdapat ancaman pidana, yang pada akhirnya mempunyai akibat hukum oleh Pasal 100 ayat (1) tersebut ada pidana untuk itu, sehingga tidak mungkin dikesampingkan pidana yang diatur dalam Pasal 100 ayat (1) tersebut oleh Pasal 100 ayat (2), yang berujung tidak adanya kepastian hukum jika pidana tersebut dijadikan sebagai upaya terakhir terhadap pelanggaran Pasal 100 ayat (1).

Sehingga Pasal 100 ayat (2) UndangUndang Nomor 32 Tahun 2009 tentang Perlindungan dan Pengelolaan Lingkungan Hidup, yang didalamnya terdapat asas ultimum remedium, yaitu upaya pidana sebagai upaya terakhir, sangat bertentangan dengan asas legalitas dalam hukum pidana, yang seharusnya pidana tersebut berjalan, namun dilanggar oleh Pasal 100 ayat (2), karena jika seseorang telah melanggar Pasal 100 ayat (1) telah memenuhi konsep pertanggungjawaban pidana, yaitu adanya unsur melawan hukum (actus reus) dan unsur kesalahan (mens rea), sehingga orang yang melanggar pasal tersebut mempunyai tannggungjawab pidana.

Jika dilihat dari sumber peniadaan pidana, maka dasar peniadaan pidana dibagi atas dua kelompok, yaitu yang tercantum dalam undang-undang dan yang lain terdapat diluar undang-undang diperkenalkan oleh yurisprudensi dan doktrin. ${ }^{11}$

Yang tercantum dalam undang-undang dapat dibagi lagi atas : yang umum (terdapat didalam ketentuan umum buku 1 KUHP) dan berlaku atas semua rumusan delik. Yang khusus, tercantum dalam pasal tertentu yang berlaku untuk rumusan-rumusan delik itu saja.

Adapun jika dikaitkan dengan pelanggaran Pasal 100 ayat (1) UndangUndang Nomor 32 Tahun 2009 tentang Perlindungan dan Pengelolaan Lingkungan Hidup yang terdapat pidana didalamnya, maka jika Pasal 100 ayat (1) tersebut akan ditiadakan pidananya harus ada dasar yang kuat, sebagaimana diatur dalam hukum

\footnotetext{
${ }^{11}$ Ibid HIm. 192.
} 
pidana umum yaitu KUHP, adapun rincian dasar peniadaan pidana yang umum itu terdapat didalam: ${ }^{12}$

1. Pasal 44 : tidak dapat dipertanggungjawabkan;

2. Pasal 48 : daya paksa;

3. Pasal 49 : ayat (1) pembelaan terpaksa;

4. Pasal 49 : ayat (2) pembelaan terpaksa yang melampau batas;

5. Pasal $50:$ menjalankan peraturan yang sah;

6. Pasal 51 : ayat (1) menjalankan perintah jabatan yang berwenang;

7. Pasal 51 : ayat (2) menjalankan perintah jabatan yang tidak berwenang jika bawahan itu dengan itikad baik memandang atasan yang bersangkutan sebagai berwenang.

Dasar-dasar tersebut diatas adalah merupakan dasar umum terhadap peniadaan suatu tindak pidana, sehingga jika dikaitkan dengan asas ultimum remedium yang menjadikan pidana sebagai upaya terakhir sangat tidak sesuai dengan dasar peniadaan pidana.

Dalam asas ultimum remedium sesuai yang diatur dalam penjelasan angka 6 Undang-Undang Nomor 32 Tahun 2009 tentang Perlindungan dan Pengelolaan Lingkungan Hidup, mewajibkan penerapan penegakan hukum pidana sebagai upaya terakhir setelah penerapan penegakan hukum administrasi dianggap tidak berhasil, selain

\footnotetext{
${ }^{12}$ Ibid, hlm. 192
}

itu disebutkan juga dalam Pasal 100 ayat (2) yang berbunyi: Tindak pidana sebagaimana dimaksud pada ayat (1) hanya dapat dikenakan apabila sanksi administratif yang telah dijatuhkan tidak dipatuhi atau pelanggaran dilakukan lebih dari satu kali.

Sedangkan menurut dasar peniadaan pidana tersebut, tidak mencantumkan setelah menjalani sanksi adminsitrasi kemudian sanksi pidana menjadi gugur/ tiada, perlu dibedakan antara aturan pidana dan aturan administrasi, keduanya merupakan ranah hukum yang berbeda dari segi pengaturannya, sanksi administrasi dikenakan jika ada pelanggaran administrasi, demikian juga dengan sanksi pidana dikenakan terhadap perbuatan seseorang yang melawan hukum dan mempunyai kesalahan.

Maka tidak serta merta ketika sanksi administrasi dijalankan, kemudian seseorang yang melakukan tindak pidana lepas dari pertanggungjawaban pidana, demikian pula sebaliknya, ketika seeorang yang melakukan tindak pidana kemudian dijatuhi hukuman pidana, tidak serta merta pula bebas dari sanksi administrasi.

Sehingga dalam hal ini asas ultimum remedium yang diatur dalam dalam penjelasan angka 6 kemudian diatur dalam Pasal 100 ayat (2) Undang-Undang Nomor 32 Tahun 2009 tentang Perlindungan dan Pengelolaan Lingkungan Hidup, sangat tidak mendasar untuk meniadakan pidana dalam 
Pasal 100 ayat (1) Undang-Undang Nomor 32 Tahun 2009 tentang Perlindungan dan Pengelolaan Lingkungan Hidup, karena bertentangan dengan dasar peniadaan pidana dalam prinsip hukum pidana.

\section{Kesimpulan}

Dalam penegakan hukum lingkungan lingkungan di Indonesia mencakup penataan dan penindakan (compliance and enforcement) yang meliputi bidang hukum administrasi negara, bidang hukum perdata dan bidang hukum pidana.

Penegakan hukum pidana dalam tindak pidana lingkungan hidup yang diatur dalam Pasal 100 ayat (1) yaitu: Setiap orang yang melanggar baku mutu air limbah, baku mutu emisi, atau baku mutu gangguan dipidana, dengan pidana penjara paling lama 3 (tiga) tahun dan denda paling banyak Rp3.000.000.000,00 (tiga miliar rupiah).

Kemudian dalam Pasal 100 ayat (2) yaitu: Tindak pidana sebagaimana dimaksud pada ayat (1) hanya dapat dikenakan apabila sanksi administratif yang telah dijatuhkan tidak dipatuhi atau pelanggaran dilakukan lebih dari satu kali.

Dalam hal ini berlaku asas ultimum remedium yang diatur dalam penjelasan angka 6 Undang-Undang Nomor 32 Tahun 2009 tentang Perlindungan dan Pengelolaan Lingkungan Hidup, yang mewajibkan penerapan penegakan hukum pidana sebagai upaya terakhir setelah penerapan penegakan hukum administrasi dianggap tidak berhasil.

Namun jika dikaitkan asas ultimum remedium ini dengan asas legalitas yang terdapat dalam Pasal 1 ayat (1) KUHP, asas ultimum remedium ini bertentangan, yaitu dalam hal mengenyampingkan pidana yang terdapat dalam Pasal 100 ayat (1) tersebut, yang seharusnya menurut asas legalitas pidana tersebut berjalan.

\section{Daftar Pustaka}

Andi Hamzah. (2015). Hukum Pidana. Jakarta : PT. Sofmedia.

Johnny Ibrahim. (2007). Teori dan Metodologi Penelitian Hukum Normatif, Malang: Bayumedia Publishing.

Syahrul Machmud. (2012) Problematika Penerapan Delik Formil dalam Persepektif Penegakan Hukum Pidana Lingkungan di Indoensia. Bandung : CV. Mandar Maju.

M. Daud Silalahi. (2014) Hukum Lingkungan dalam sistem penegakan hukum lingkungan Indoensia. Bandung : PT. Alumni.

\section{Peraturan Perundang-Undangan:}

Kitab Undang-Undang Hukum Pidana

Undang-Undang Nomor 32 Tahun 2009 tentang Perlindungan dan Pengelolaan Lingkungan Hidup. 